\title{
Responses to Flood Disaster: Use of Indigenous Knowledge and Adaptation Strategies in Char Village, Bangladesh
}

\author{
Babul Hossain (Corresponding author) \\ Department of Sociology, School of Public Administration \\ Hohai University, Nanjing, China \\ E-mail: hossainbabul@hhu.edu.cn \\ Chen Ajiang \\ Department of Sociology, School of Public Administration \\ Hohai University, Nanjing, China \\ Crispin Magige Ryakitimbo \\ Department of Sociology, School of Public Administration \\ Hohai University, Nanjing, China
}

Received: August 8, 2019 Accepted: September 6, 2019 Published: September 17, 2019

doi:10.5296/emsd.v8i4.15233

URL: https://doi.org/10.5296/emsd.v8i4.15233

\begin{abstract}
The present study attempts to analyze flood disaster phenomenon on local char village and the people's adaptation strategies against the catastrophe flood in the char. This study predominantly is qualitative. At the same time, quantitative data have also been used for doing research meaningfully. After the field survey, the empirical sociological analysis reveals that the socio-economic impact was worsened. This impact showed that almost $100 \%$ of crops land washed, $49 \%$ of livestock fully damaged, $70 \%$ of people lost their income as well as $35.2 \%$ of house fully damaged, $95.2 \%$ of households loss of food stock and most of the sanitary facilities affected due to the extreme flood in 2017 at kalur para Char village of Fulchari Upazila (Sub-district). Regarding this matter, local people took some of their strategies to alleviate the intensity of the flood disaster, which helped them to survive. These
\end{abstract}


strategies were categorized into three phases, i.e. before, during and after the flood. At the time of field survey, it was found that people were mainly engaged to raise the house from the ground, stockpile dry and constant food, move their livestock to safer palaces, sow rapid growing paddy, take shelter in high places, purify drinking water by boiling before and during the flood. After the flood, some measures taken by people were also identified, i.e. regarding financial solvency people took a loan from various organizations, grow short time crops, explore new work opportunities etc. As a result, the severity of the flood is somewhat reducing, and the affected people are also getting pluck to survive against the flood.

Keywords: Flood Disaster, Char Village, Socio-economic Impact, Adaptation Strategies, Indigenous Knowledge

\section{Introduction}

Bangladesh is one of the most vulnerable countries to numerous flood disasters, and every year flood distressed people's lives in a particular part of the country. The country entire area is approximately $147,570 \mathrm{sq}$. $\mathrm{Km}$ and it has enclosed between $20^{\circ} 34^{\prime}$ to $26^{\circ} 38^{\prime} \mathrm{N}$ latitude and $88^{\circ} 01^{\prime}$ to $92^{\circ} 41^{\prime} \mathrm{E}$ longitude. It has occupied a unique geographical location, spanning an expanse of land between the mighty Himalayan mountain chain on the north side and the Bay of Bengal on the south side. It is nearly the only drainage channel for a gigantic river basin complex (Tajrin \& Hossain, 2017; UNEP, 2001). The rivers of Bangladesh are the most significant features of its landscape. Bangladesh has 250 rivers with the network, and it is predominantly known as "Bengal Delta" which is the largest in the world. The delta country is mostly made up of alluvial soil deposited by the three main river systems Ganges, Brahmaputra, and Meghna rivers (Mohammad Zaman \& Wiest, 1991).

The flood phenomenon in South Asia is predominantly operated by the exceptional hydro-meteorological, and also in this region has monsoonal influences. In this reason, there are two types of monsoonal windows are functioning, i.e. one is the southwest monsoonal window which is followed in the summer months, and the northeast monsoonal window follows in the winter season (Rasid \& Paul, 1987). The southwest monsoon generally enters from June to September, and $70-80 \%$ of the rainfall conduces in this area. Besides, the dissolution of glaciers in the foot of Himalayan-Hindu Kush region, owing to tangible climate change impact may also contribute to an escalation in flash floods in the mountainous zones, and those areas are situated at the foothills (Rahman, 2014). Due to rapid increase of population in the Indian Subcontinent for the present century has resulted in a rushing of deforestation in the hills of Nepal to meet the cumulative demand for fuel wood and food (Bajracharya, 1983), (Ives, 1989; Sharma, 1991), Deforestation of steep slopes is presumed to lead to enhanced soil erosion and landslides during monsoon precipitations. For this reason, the overwhelming floods in the downstream regions, such as in Bangladesh is increasing day by day (Munna, 2007). The most of the part of Bangladesh is low-lying, and almost $80 \%$ of the landmass is flood-prone, for this reason, the country is relatively more vulnerable to the jeopardy of recurrent floods (Khan \& Nahar, 2014). In the perspective of Bangladesh, Floods are an annual phenomenon, and it appears with severe during the month of July and August every year. Even though in a typical year, due to the flood disaster, one-tenth of the total land 
surface is harshly hit (MQ Zaman, 1988).

The devastating flood occurred in Ganges-Padma, Brahmaputra floodplain in 1987, 1988, 1998, 2004, 2007 and 2017. So, 2017 flood is the recent deleterious flood in Bangladesh. After the overwhelming flood in 2017 flood in July, on 12 August started the second phase flood and submerged 31 districts (Management, 2017). From this phase, it disrupted people's daily life. There were 1200 union affected out of 183 upazilas (Sub-district) under the 31 districts, and also 8746 villages were affected due to the flood in 2017. Besides, there were respectively 238843 and 6536509 people fully and partially affected, respectively, 50042 and 1305257 households were affected fully and partially. Many people got an injury due to flood, and almost 121 people died. On the other hand, respectively 15529 and 562594 hectares agricultural land fully and partially inundated. In addition, there were 34 and 3134 educational institute fully and partially damaged, and respectively $4432.38 \mathrm{~km} 403$ of road fully and partially damaged, 268 and 96 bridge and dam also were damaged (Nirapad, 2017).

During the flood in 2017, most of the people were lost their all livelihood equipment. The intensity of flood disaster has baffled people healthy life. Mainly, Char land is one of the most vulnerable for the magnitude of damage. Eve Gruntfest proves that owing to high poverty levels; people have to get more defenseless because they live in dangerous zones including floodplains like the char of the river and over the embankment (Gruntfest, 1995). According to Barkat et al. opined that due to the geographical location of char land, poverty and vulnerability are highly determined than the plain land areas (Barkat, Roy, \& Khan, 2007). On the other hand, Baqee showed that doubtfulness of the lives and livelihood of the dwellers of char land in Bangladesh (Baqee, 1998). The char-dwellers are trying to cope with this adverse flood situation though they have low adaptive capacity due to extreme poverty, recurrent natural hazards and overwhelming dependence on nature. For the char dwellers who are living in the multi-flood prone areas since a long time, repetitive flood and riverbank erosion phenomenon aren't new scenarios (Najmul Islam, Zahurul Islam, \& Fujita, 2011). For this reason, the Char dwellers are involved in an endless fight for surviving against flood and riverbank erosion disaster. This kind of attempts has to lead them a massive deal of knowledge to fight with the frequent floods disaster. Over the course of this process, the people of char land are facing enormous asset, economic losses and also social insecurity. Regarding this matter, for the vulnerable communities, how they alleviate such damage, insecurity and losses is a great challenge. For this situation, here is a clear gap to conduct of in-depth research on household-level responses and coping strategies by the char-dwellers to reduce damages from recurrent flood hazards in this highly populated disaster-prone country. Schmuck-Widmann et al. attempted to explain the Jamuna char land people's coping strategies and prepared an assessment between local and engineering knowledge's experiences for the action against natural disasters (Schmuck-Widmann, 2001). She also tried to find out how the char land people realized the Jamuna River and its character, and how they followed the tactics to cope with the monomania of the river. S. N. Islam et al. tried to investigate the phenomenon of floods in the river basins and reason of the intimidation, about create a long term tactic for the char land settlement relocation (A. S. Islam, Haque, \& Bala, 2010). They also found that the char land people aren't durable in their land due to a 
monsoon flood disaster. Sirajul Isalm and M.S. Islam tried to find out about the char land people's livelihood impacts of flood and riverbank erosion and people adaptation techniques. Besides, they also focused on the organizational role and how they support to the affected people (M. Islam, Sultana, Saifunnahar, \& Miah, 2014), (Md Sirajul Islam, Solaiman, Islam, Tusher, \& Kabir, 2015). Emmanuel Mavhura stated that indigenous knowledge systems played a significant role in reducing the impact of the flood. And he also tried to find out some local people initiatives that measures can be helped them to resilience from flood disaster (Mavhura, Manyena, Collins, \& Manatsa, 2013). Therefore this study is an attempt to unbolting the flood disaster phenomenon on char people and how the people are surviving against the flood.

\subsection{Char Land in Bangladesh}

Bangladesh is a flood plain country which consists of rivers and island water bodies (Ahamed, 2001). Char land is such kind of Bengali term for Mid-channel Island, and as a result of accretion, it emerges from the riverbed (Elahi, 1991). Basically, char land is upland; and it comprises storage of sedimentation for a long time rowed by the river from the upstream mountainous area. Besides, it is formed in 2-3 years and it is a return of the river. As the river erodes one side of river and creates land on the other side. [Bhanga and Gora' (which translated means annihilation and rebuilding)is the main character of the phenomenon for such chars, there are many folk songs in Bangla music regarding explain its nature](Hakim, 2012). When a river changes its track, then it erodes one part of the settlement on durable land. It is due to the devious effect of the river. So, in this regard, when people become sufferers of losing land, then they go to another char land area or nearby town to settle down there(Adham \& Rubayet, 2010). There are five sub-areas of char land have in Bangladesh such as Jamuna, Ganges, Padma, upper Meghna, and the lower Meghna river. Besides the old Brahmaputra and Teesta also set up some char land areas (M. Islam, Hasan, Chowdhury, Rahaman, \& Tusher, 2012).

The entire of char land is mainly very unsteady and prone to susceptible annual flooding. The dwellers of char land are relatively most impoverished and one of the most vulnerable people predominantly those who live alongside the island or attached the river bank chars(Roy, Syed, \& Azim, 2007). Floods are one of the main natural disasters encountered by char land communities. Even during the normal monsoon floods in the char areas tend to be last for weeks rather than months, but the flood can happen a small number of times in the period of monsoon season (Tod, 2007).

The common phenomenon of this area is that household and individual movement is very high and temporary and permanent displacement is a common scenario in these areas. Most of the char land people are literally have been forced to move at least once during this period owing to erosion (Kar \& Hossain, 2001). People face arranging entrée to productive land, and the other sources are also vastly vulnerable. The char land communities are mostly left out from the mainland services and don't represent an importance for mainland leased government administration. In the char areas, people are seeking for proper health treatment, education and various social services, especially for women and children (Md Sirajul Islam et 
al., 2015). The entire char land is very fragile, and it's prone to magnitude annual and seasonal flooding. Concerning this, high-extreme disaster events cause immense loss and havoc.

\subsection{Indigenous Knowledge}

Knowledge is well-defined by the Oxford English Dictionary as 'information and skills acquired through education or experience' or an 'awareness or familiarity gained by experience of a fact or situation'. Then this can be divided further into 'scientific knowledge' and 'indigenous knowledge' (Hakim, 2012). The term indigenous knowledge has various meaning such as local knowledge, traditional knowledge, technical knowledge, peasants knowledge, and also folk knowledge (Cadag \& Gaillard, 2012; Gaillard \& Mercer, 2013; Mercer et al., 2012), (Sillitoe, 1998). To abridge pertinent literature, indigenous knowledge is measured to be a body of knowledge existing within or attained by local people over some time through an accretion of experiences, society-nature relationships, community practices and organizations, and by passing it down through generations (Brokensha, Warren, \& Werner, 1980). Scientific knowledge is universal in nature, while indigenous knowledge is considered local. However, indigenous knowledge is dynamic in nature, as with scientific knowledge, repeatedly influenced both by inner creativity and investigation and by interaction with outward systems (Flavier, Jesus, \& Navarro, 1995).

The present study recommends an examination of flood disaster from a people-centred viewpoint: that is what the inhabitants know about flood disaster threats and what they trust and do about them in a given condition. As such local knowledge is used here in its widest sense. We all have local knowledge: it denotes to the connection people progress with their environments over time. Indigenous knowledge is part of local knowledge: it denotes to: "local knowledge held by indigenous people or local knowledge exclusive to a given culture or society." (Berkes, 1999) Local states to, and emphasizes, a place, an area, a site as much as the consistent movements between different points (e.g., knowledge linked to the routes or diverse areas of groups of people who migrate on a routine basis such as nomads, commuters, seasonal migrants (Antweiler, 1998) rather than time (a knowledge that is anterior to another, traditional versus contemporary knowledge). (Bank, 1998) It is indispensable to study how people (local and indigenous) in a specific area view and interrelate with their; whether or not they have local knowledge that reliefs monitor, interpret, and respond to spirited changes in ecosystems and the resources and services that people produce; and whether or not their knowledge can be used to design appropriate interventions, including disaster preparedness (Berkes, Colding, \& Folke, 2000; Mohammad Shahriar Islam, 2007) Local knowledge is vigorous and is always altering over time through experimentation and adaptation to environmental and socio-economic changes (Maferetlhane, 2012; Thrupp, 1989).

Most of the people of Bangladesh who live in disaster-prone areas depend on indigenous knowledge to alleviate the thrilling climate such as flood, riverbank erosion, cyclone, drought, etc. In this modern era, even though the disaster-related update is circulated very fast, in most of the cases, the affected vulnerable people have not received philanthropic support rapidly. The affected people find out their ways to survive against the disaster until the GOs and 


\section{Macrothink}

NGOs assistance reaches to a disaster-affected area. The historical evidence shows that the vulnerable people of Bangladesh have confronted catastrophic conditions by spreading their co-operation with their local knowledge from time immemorial. Therefore, this knowledge is an essential technique to alleviate the disaster losses during the period of disaster.

\section{Study Area}

The present study has been conducted on char village. The name of char village is Khalur Para. The Union Parishad Chairman of Fuchari and also local people stated that khalur para char village has contained before the overwhelming 1988 flood and it is running till now. Kalur Para Char village is situated at Fulchari Upazila in Gaibandha district of Bangladesh. The Village located between $25^{\circ} 15^{\prime}$ and $16^{\circ} 14^{\prime}$ north latitudes and between $89^{\circ} 40^{\prime}$ and $04^{\circ} 15^{\prime}$ east longitudes. (According to Google earth). The total area of this village is $1.88 \mathrm{sq} . \mathrm{km}$. There are 899 households have in this village, and the entire population is 3596 . The average literacy rate of this village is $17 \%$ (UPO). This area is lowland, severely flood-prone area alongside the Brahmaputra River. Most of the houses are made with the tin and mud, thatch roofs and 'Kaisha' made walls. Corrugated Iron (CI) sheets make some of the house roofs. But the walls are made of 'Kaisha,' jute stick and CI sheet.

On the other hand, the communication system is not well. Majority road is muddy. The significant basis of livelihood in the study area is agriculture. In addition to this, seasonal labor, services, and businesses are other sources of maintaining the livelihood. Most of the population of this area depends on seasonal agriculture and animal husbandry. Rice, potato, Jute, green Chilly, Banana, wheat, sugarcane, pumpkin, tomato, etc. are the main products of this area.

Nearly every year people of this village experienced a riverine flood. On average, the flood length was 15-25 days in the homestead and 1-2 months in agriculture field found from the respondents. According to the interview of the village people of the study area, it seems that the presence of a canal and tributaries, inside of the union, is one of the leading causes of the regular flood. Data found that there is a primary school and a madrasah (religion institute) located in this village. There are no flood shelters in this area. So, all educational institutes are used as a flood shelter during a flood situation. 


\section{Macrothink

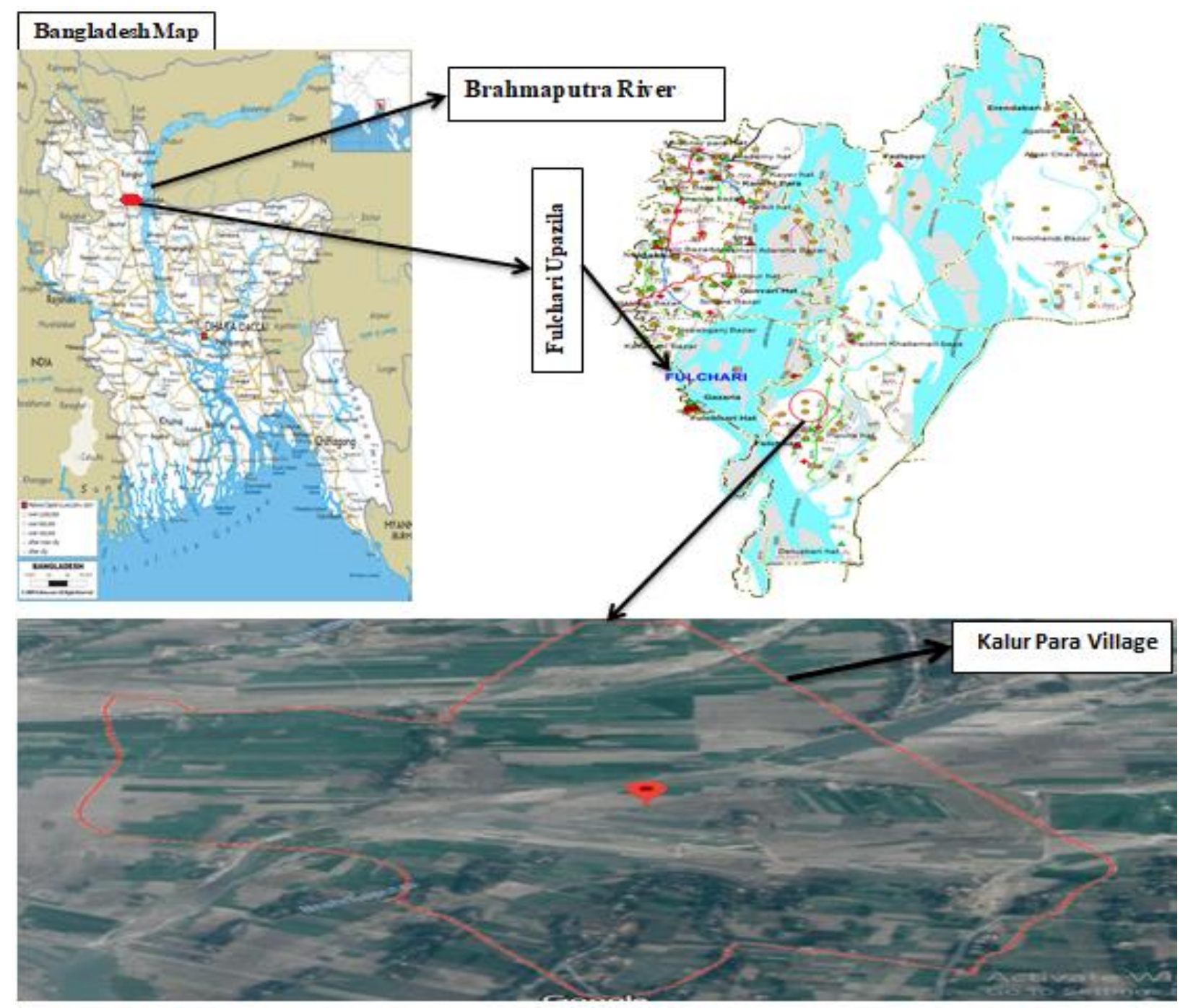

Figure 1. Map of the study area location

\section{Conceptual Framework}

The present study is running on the basis of some logical points of view, which are the main terminology to focus on this research. The flood phenomenon of Bangladesh, especially in the char area is very ruthless. Every year the char land people face the adverse flood and it has already become familiar with the char people is a curse. So, with the various institutions, the local people take some strategies to get rid of catastrophe flood disaster. The local people usually used to their strategy by the previous flood, during the flood, post flood. These three types of approaches are very fruitful to survive the flood period. However, the whole process of this study is visualized in the following figure. 


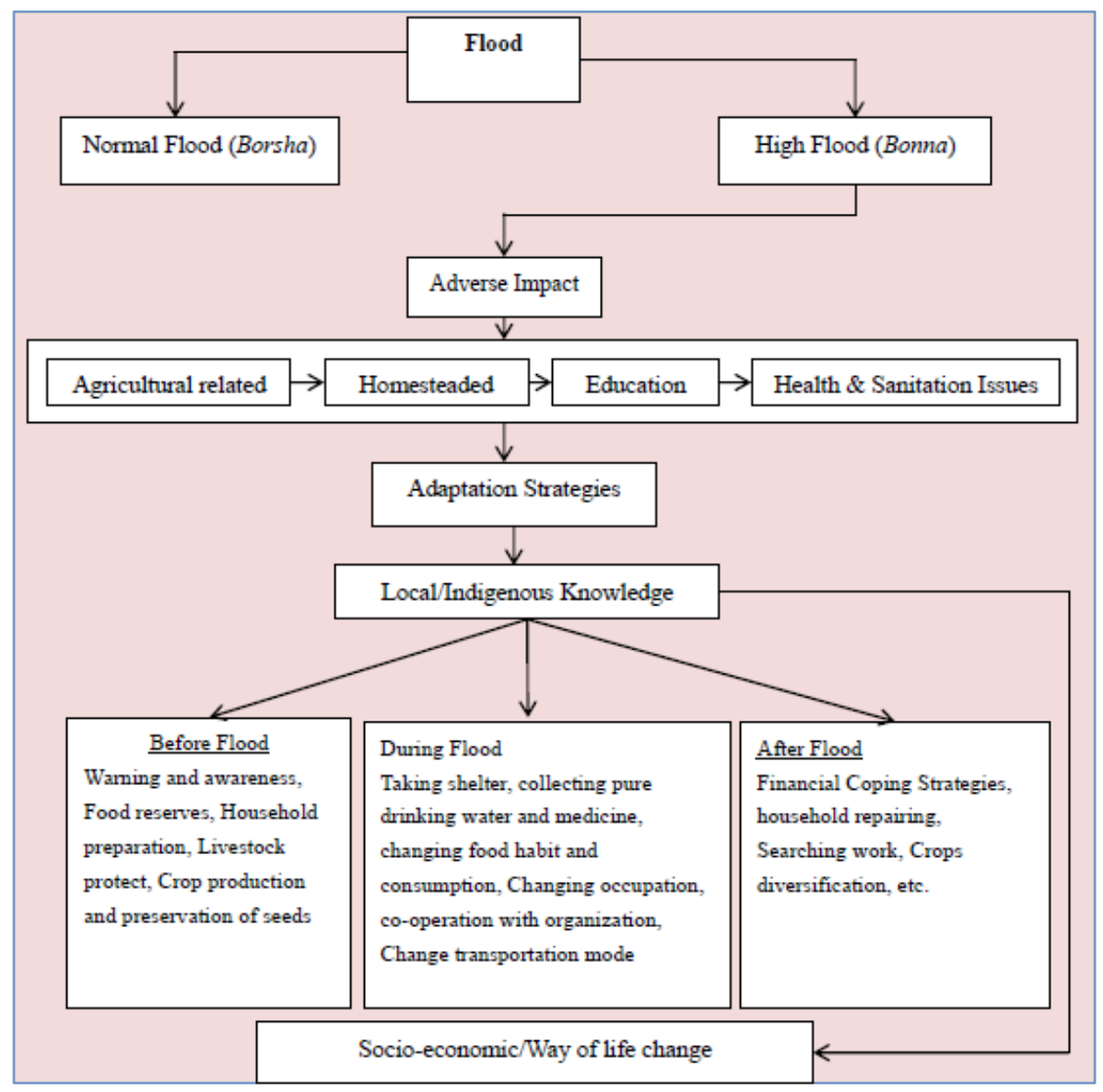

Figure 2. The Conceptual Framework

\section{Methodological Approach}

The present study is tried to unbolting the flood disaster phenomenon on char dwellers and also to know how to people are surviving against the overwhelming flood by using indigenous knowledge in the char areas at Gaibandha district of Bangladesh. For doing exploratory research, the researcher was done reconnaissance survey or the first visit to the study area for realizing the study environment through observation and conversation with the affected people. This process is helped to understand the possibility of carrying out the study in that area and also might be improved to design the questionnaires. Five days long reconnaissance survey was brought to pass in Gaibandha district. After reconnaissance survey and reviewing literature, the survey questions and checklist for interviewing have been prepared for collecting data. This research is predominantly qualitative, and at a time, quantitative data have also been used. Consequently, a mixed approach has been succeeded to do this research profoundly.

The study area is relatively more vulnerable to a repeated flood disaster. Every year the country experiences a flood, riverbank erosions and cyclone disasters displacing literally hundreds and thousands of people annually. Of these, flood disaster or bonna (i.e., high flood) 
has become fairly regular, although until recently, it was almost a decennial event. During high floods, people lose their homes and hearth, crops and other assets, and are displaced temporarily - and for many permanently. Regarding this matter, we have taken the 2017 flood for doing this research. There are 899 households in Khalur Para char village (Union Parisad Office). According to the field survey, almost $100 \%$ of households were affected by the catastrophe 2017 flood disaster. So, concerning this issue, we have used Cochran's Formula (Cochran, 1977) for getting the actual sample size for doing the research.

$$
\begin{aligned}
& N_{0}=\frac{Z^{2} p q}{e^{2}}=\frac{(1.96)^{2} \times(0.5) \times(0.5)}{(0.05)^{2}}=\frac{0.9604}{0.0025}=385 \\
& n=\frac{n_{0}}{1+\left(\frac{n_{0-1}}{N}\right)}=\frac{385}{1+\frac{385-1}{899}}=\frac{385}{1+0.43}=270
\end{aligned}
$$

Here, $\mathrm{n}=$ sample size, $\mathrm{N}=$ total number of households, no= Cochran's sample size recommendation, $\mathrm{z}=$ confidence level (at 95\% probability $=1.96, \mathrm{p}=$ estimated population proportion (0.5 this maximizes the sample size), $\mathrm{q}=1-\mathrm{p}, \mathrm{e}=$ error limit of $5 \%(0.05)$

Therefore, we have acquired 270 households out of 899 households by using Cochran's sampling techniques formula. There are two times frame have been considered for collecting data. The first phase has been stared from July to September 2017, and the second phase started from December 2017 to February 2018. Primary data have been collected through a questionnaire survey, face to face interview, focus group discussion and observation. The key informant interview was carried out to collect vast information from who know about flood disasters such as school teachers, community leaders, and member of Union Parishad and officials of GOs and NGOs experts. On the other hand, focus group discussion has been conducted at the village level with the help of pre-assigned checklist with a view to finding out indigenous coping strategies to a magnitude flood disaster. Every each of the FGDs group had 6-10 number of people participated. This study has also been used as an ethnography technique to a better understanding of the respondent's perspectives. This technique helped the researchers to observe and interact with the respondents in their real-life scenario and flood disaster losses. And also the secondary data has been collected through reviewing various kinds of literature, Books, published and unpublished thesis and different websites.

After completing the data collection, interview sessions have been scrutinized analyzing according to the objectives of the study. IBM Statistical Package for Social Science (IBM-SPSS) software version 20 has been used for analyzing quantitative data and has also been used Graphics software. On the contrary, qualitative data have been interpreted by textual and document analyses. The collected secondary data have been accomplished, scrutinized, verified and reviewed by the researchers to get around the overlapping, inconsistency and error as well as the edited data have been classified and presented by various tables, chart, graphs and diagrams to do those more impressive and spontaneously realizable to the reader. The researchers have also given his clarifications to the analysis of primary and secondary data and interview on the basis of findings and observations. 


\section{Result and Discussion}

\subsection{Socio-economic Impact}

The word 'socio-economic' is used to delineate something that relates to or is concerned with the interaction of social and economic factors. It is generally, income and social position that is used to degree the status of a family or an individual in a community. Socio-economic factors comprise of income, education, occupation, and involvement in the community (Edwards, 2000).Flood is the most severe disaster in Bangladesh. There are many flood-prone areas in this country. Every year, flood attacks of these places but the intensity is not the same each affected locations. The Brahmaputra river basin area is one of the most vulnerable places in terms of flood and riverbank erosion of which flood is the recurrent phenomenon. Every year millions of people are affected due to extreme flood and also thousands of people are displaced. Due to the flood occurred of Gaibandha district, people become more vulnerable, and they lost their almost everything alongside the livelihoods facilities.

\subsubsection{Agriculture and Livestock Related Impact}

Bangladesh is mainly an agricultural country. Almost $80 \%$ of people are engaging in agriculture directly and indirectly. The present study revealed that almost $100 \%$ of respondents cultivate crops before the 2017 flood period, and they lost their crops fully due to the adverse effect on crops field by the flood. Besides, some people in the study area have no land, but they cultivate crops by taking the lease. Local people stated that paddy, wheat, corn, pepper, jute are the main crops of this reason. During the flood, agrarian land in submerged severely which depend on the intensity of flood.

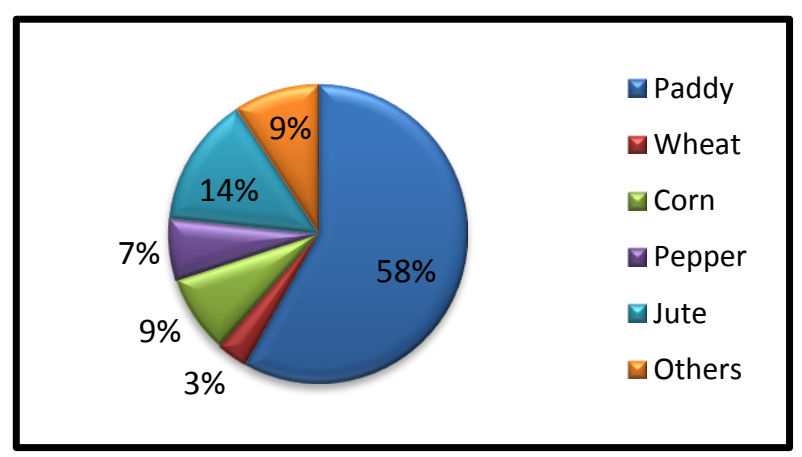

Figure 3: Crops Loss

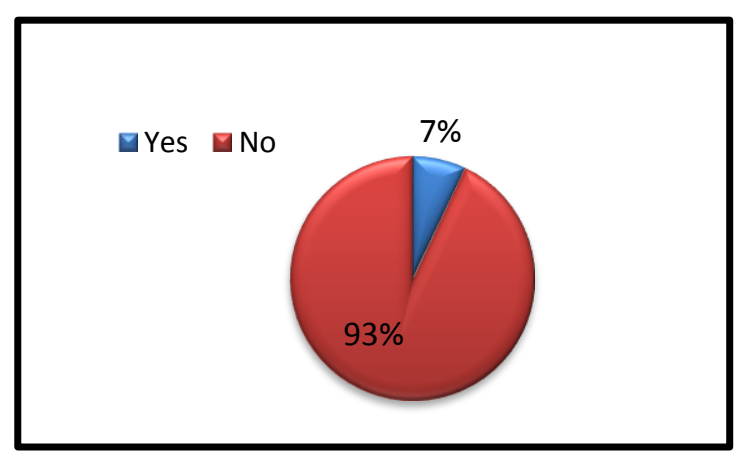

Figure 4: Fishing Activities

Paddy is one of the main crops of Bangladesh. As $100 \%$ of crops have been fully damaged of which 58\% paddy, $14 \%$ Jute, 9\% Corn, 7\% Pepper, 3\% Wheat, and 9\% others. On the other hand, when the flood disaster happens for a long duration, due to riverbank erosion, the people lost their land/agricultural land those who land is near to the river. Siltation is one of the leading causes to make agricultural land more infertile and decrease the productivity of the land during the flood. From figure 3 showed that the loss of the main crop is paddy, which 


\section{Mll Macrothink}

damaged $58 \%$ out of $100 \%$. In addition, some people also involved fishing activities in the study area. Figure 4 showed that only $7 \%$ of people engaged a fishery, and the damage was full during the 2017 flood. On the other hand, $93 \%$ of people did not involve with fishery.

Table 1. Livestock related information

\begin{tabular}{|l|l|l|l|l|}
\hline Category & Variable & Frequency & Percentage & \\
\hline \multirow{2}{*}{ Livestock } & Yes & 257 & 95.2 & \multirow{2}{*}{$100 \%$} \\
\cline { 2 - 4 } & No & 13 & 4.8 & \\
\hline \multirow{2}{*}{ Damage livestock } & Fully & 126 & 49.03 & \multirow{2}{*}{$100 \%$} \\
\cline { 2 - 4 } & Partially & 131 & 50.97 & \\
\hline \multirow{2}{*}{ Force to sell livestock } & Yes & 126 & 96.18 & \multirow{2}{*}{$100 \%$} \\
\cline { 2 - 4 } & No & 5 & 3.82 & \\
\hline
\end{tabular}

Most of the respondents reported that they had livestock before the flood, and only 13 respondents told that they had no livestock. When the 2017 flood struck of the study area that time 126 households damaged their livestock fully. On the contrary, 131 households damaged their livestock partially.

During the flood, people become helpless and hopeless. They always time try to live safely. Regarding this matter, people want more help from different organizations and local people for their safe life. Even though many families had livestock, they had to force to sell their livestock to meet basic needs during the flood. The present study revealed that there were 126 households forced to sell their livestock and only 5 households didn't sell the livestock.

\subsubsection{Occupations and Income}

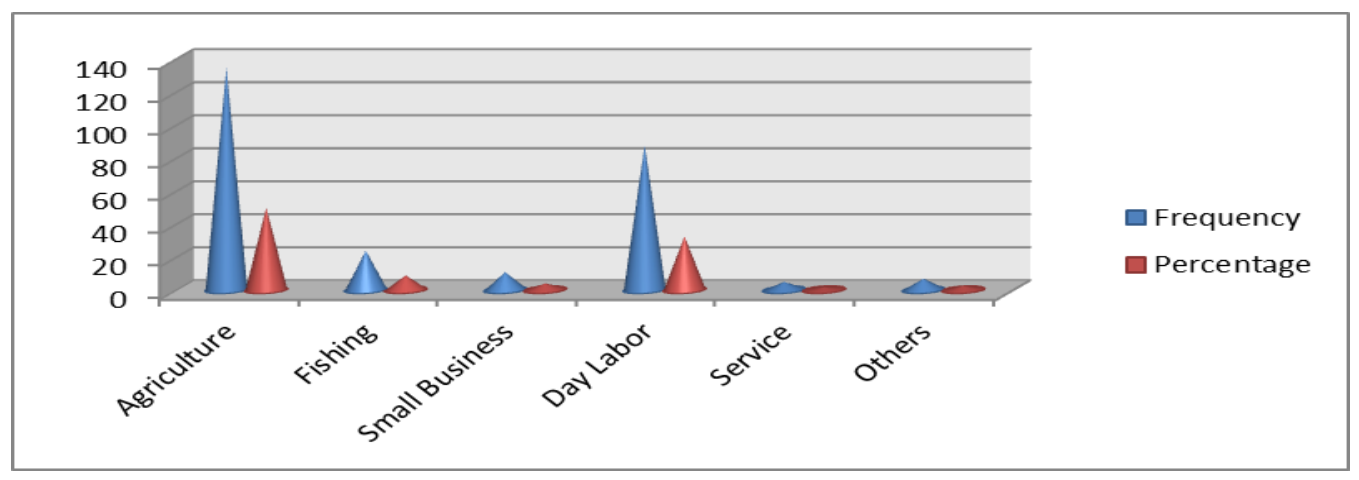

Figure 5. Occupation and Income of the respondents

Bangladesh is mainly an agricultural country, so most probably people are engaging with agriculture. In the field survey, it is shown that 135 respondents informed that agriculture is the main occupation of us. On the other hand, 88 respondents stated that our earning source is day labor. The farmers and agricultural labor's livelihood are directly reliant on agriculture. So, there is a substantial relationship between the two groups. Respectively $24,11,5,7$ were 
fishing, small business, service, and others. This study also showed that the education rate of this area is below 20\%. For this reason, the service person rate is very low. People became work-less during the flood period. The respondents stated that they lost their income generating activities (IGA) when the flood struck. Most of the farmers became landless and jobless during the flood. Especially the people of Char land faced more striving in finding any substitute work at that time. On the contrary, the income of boatmen declined during the flood than other times as they get a very fewer passenger to carry. Besides, Small businessmen also faced a very uncomfortable situation for carrying their good to another place during the flood period. In the 2017 flood, 189 respondents (70\%) lost their income during the flood.

On the other hand, 81 respondents didn't lose their income totally, but they lost their main source of income. They just have diverted source of income. Besides, the affected people also reported that during the flood and after the flood like 20-25 days, they couldn't find any income source. Some of the people diverted their source of income, but the income wasn't sufficient as they earn income previously.

\subsubsection{Homestead Related Impact}

Table 2. Homestead information of the respondents

\begin{tabular}{|l|l|l|l|}
\hline Category & Variable & Frequency & Percentage \\
\hline \multirow{2}{*}{ Damage house } & Partially damaged & 175 & 64.8 \\
\cline { 2 - 4 } & Fully damaged & 95 & 35.2 \\
\hline \multirow{2}{*}{ Force to relocate } & Yes & 208 & 77.0 \\
\cline { 2 - 4 } & No & 62 & 23.0 \\
\hline \multirow{2}{*}{ Lied family members } & Yes & 8 & 3.0 \\
\cline { 2 - 4 } & No & 262 & 97.0 \\
\hline Source of drinking water & Tube well & 257 & 95.2 \\
\cline { 2 - 4 } & Yorehole & 5 & 4.8 \\
\cline { 2 - 4 } & No & 265 & 98.1 \\
\hline
\end{tabular}

Home is one of the basic needs of the human being to live. But there are some natural disasters which baffle normal human life. Else, this disaster not only baffles human life but also destroy each and everything. Flood is the worst natural disaster in Bangladesh. Every year, the flood attacks in this country. The present study revealed that every household damaged in study area due to the 2017 flood. In the above table 2 showed that among the 270 households 175 households partially damaged and 95 households fully damaged. As a result, people did not live properly during the catastrophe flood in 2017.

For this reason, People forced to relocate to the other places to live. According to the table-2, 208 households' family members $(77 \%)$ forced to relocate the other safe places, and 62 household family members $(23 \%)$ did not go to other places. They tried to live their home against the flood. Due to the flood, the household lost their some family members. During the 


\section{Macrothink}

2017 flood, 8 households lost their family members, and each family lost a member. Among the eight people, most were infant, sickness and older. Food is essential for being alive to any crises. During the 2017 flood, 257 households (95.2\%) loss of food stocks and only 13 (4.8\%) households did not experience loss of food stocks. Pure drinking water is very crucial during the flood, but every household lost their drinking water facilities. The respondents stated that $265(98.1 \%)$ households provide their drinking water from the tube well, and only $5(1.9 \%)$ household receive their drinking water from the borehole. For this reason, owning to intrusion flood water most of the tube well and borehole sank under the flood water. Regarding this issue, people did not meet pure drinking water.

\subsubsection{Education Facilities Impact}

Table 3. Impact of flood on education facilities

\begin{tabular}{|l|l|l|l|}
\hline Category & Variable & Frequency & Percentage \\
\hline \multirow{3}{*}{ School Damage } & Yes & 270 & 100 \\
\cline { 2 - 4 } & No & 0 & 0 \\
\hline \multirow{2}{*}{ Children Disruption to go to school } & Yes & 270 & 100 \\
\cline { 2 - 4 } & No & 0 & 0 \\
\hline \multirow{2}{*}{ Reason for Disruption } & Road Impassable & 217 & 80.4 \\
\cline { 2 - 4 } & Bridge Culvert washed away or submerged & 14 & 5.2 \\
\cline { 2 - 4 } & School submerged/ surrounded by water & 39 & 14.4 \\
\hline
\end{tabular}

Education is the backbone of a nation (Michael F. Easley). It is also a basic need for a human being. So, this phenomenon gives a man to go to lighthouse that can build up as an ideal man. But if it disrupts several times, then it's not good news. Flood is one of the most disrupt path in this study area for better education. In the 2017 flood, almost all school submerged. The education facility was a very worn-out condition. And all household who have student did not go to school for studying.

There are some variable to disrupt education during the flood. In the 2017 flood, $80.4 \%$ of education disrupted by road impassable, and $5.2 \%$ of bridge culvert washed away. On the contrary, $14.4 \%$ for school inundated or surrounded by water. Besides, local people stated that during the flood disaster, education institute used as a shelter house, that's why education activities disrupted for a long time.

\subsubsection{Health and Sanitation}

Table 4. Heath and Sanitation problem due to flood

\begin{tabular}{|l|l|l|l|}
\hline Category & Variable & Frequency & Percentage \\
\hline \multirow{2}{*}{ Sick of a household member } & Yes & 245 & 90.7 \\
\cline { 2 - 4 } & No & 25 & 9.3 \\
\hline \multirow{2}{*}{$\begin{array}{l}\text { Diseases were experienced by } \\
\text { the household members }\end{array}$} & Diarrhea & 129 & 47.8 \\
\cline { 2 - 4 } & Cough/ ARI & 97 & 35.9 \\
\hline
\end{tabular}




\begin{tabular}{|l|l|l|l|}
\hline \multirow{5}{*}{ Damage to health facilities } & Malaria/ Fever & 32 & 11.9 \\
\cline { 2 - 4 } & Others & 12 & 4.4 \\
\hline \multirow{5}{*}{ Types of damage } & Yes & 270 & 100 \\
\cline { 2 - 4 } & No & 0 & 0 \\
\hline \multirow{5}{*}{ Sanitary facilities } & Don't meet treatment on time & 92 & 34.0 \\
\cline { 2 - 4 } & Lack of Medicine & 17 & 6.3 \\
\cline { 2 - 4 } & Lack of proper physician & 18 & 6.7 \\
\cline { 2 - 4 } & Both & 143 & 53.0 \\
\hline \multirow{5}{*}{ Sanitary facility affected } & Pucka & 114 & 42.2 \\
\cline { 2 - 4 } & Semi-Pucka & 9 & 3.3 \\
\cline { 2 - 4 } & Kutcha & 134 & 49.6 \\
\cline { 2 - 4 } & Hanging toilet & 8 & 3.0 \\
\cline { 2 - 4 } & Others & 5 & 1.9 \\
\hline Sanitary facility damage happened & Yes & 270 & 100 \\
\cline { 2 - 4 } & No & 0 & 0 \\
\cline { 2 - 4 } & Partially damaged & 10 & 3.7 \\
\hline & Fully damaged & 260 & 96.3 \\
\hline
\end{tabular}

According to the above table-4, it mentioned that in the 2017 flood among the 270 households 245 (90.7\%) households members got sick and 25 (9.3\%) households members did not get sick. The Char land dwellers feel pain from several water-borne diseases such as diarrhea, cough, fever, dysentery, skin diseases, etc. during the flood period of which 129 (47.8\%) household family members were experienced by the diarrhea disease and 97 $(35.95 \%)$ households were experienced cough. On the other hand, 32 (11.9\%) households family member got sick by the fever, and only 12 (4.4\%) households were experienced others diseases. During the 2017 flood, almost all health facilities damaged. For this reason, the household member had not taken proper treatment. Besides, during the flood period, char land people were often bitten by snakes and water insects.

Health facility is an essential matter for vulnerable people. But in the 2017 flood period, almost all health-related activities were damaged. Due to some reason, people had not gotten proper treatment during the flood period. There are 92 (34\%) of respondents stated that did not meet treatment on time, and $17(6.3 \%)$ of respondents reported about lack of medicine. On the other hand, $18(6.7 \%)$ of respondents gave their opinion about the lack of proper physician and $143(53 \%)$ of respondents given their valuable advice about above both of reason.

Sanitary facility is also an essential part of keeping a healthy life. In the study area, most of the households use kutcha latrine (49.6\%), and $42.2 \%$ of households use the pucka latrine. On the contrary, respectively semi pucka and hanging toilet uses $3.3 \%$ and $3 \%$. And only $1.9 \%$ of households use other latrines. During the recent flood of the study area, all household's sanitary facilities affected of which $3.7 \%$ household's sanitary system partially damaged and $96.3 \%$ household's sanitary system fully damaged. 
After the above discussion, it is cleared that the socio-economic impact of the flood on Char land people was much worsened. Most of the people lost their crops and income generating activities (IGA) and also damaged their home and hearth. Majority of the char land people in this area have very lower income. When the flood hits this area, these lower-income people were more vulnerable than the people who had a handsome income. During the flood period, most of the poor people failed to meet their minimum life standard needs. The stranded people could not meet the expense of daily food, medicine, and other basic needs.

\section{People Adaptation Strategies by Indigenous Knowledge}

Bangladesh is a very disaster-prone country like a flood, cyclone, river bank erosion, etc. Every year these kinds of disaster attacked some part of the country of which flood is the repeated phenomenon. As a result of the extreme flood like 2017 flood, people loss their livelihood capacity. In addition, the people of Char area are more vulnerable due to high poverty. As in the char areas, the people are basically farmers. Due to the magnitude flood disaster, farmers lose their innumerable crops, and consequently farming is one of the most vulnerable occupations. So, when the households suffer a shock such as the flooding, the household members don't remain inactive. For this reason, to manage this problem, people of Char land articulated and carry out several adaptation strategies in their way which differs depending on their socio-economic and environmental features, income, occupations, education, and way of life conditions, etc. Regarding the 2017 flood, the local people had also taken their indigenous coping strategies to defend. In this study, the researchers have been tried to find out the people existing adaptation strategies by using indigenous knowledge to flood in Kalur Para Village.

\section{Early Warning Practices}

For the preparedness process, people need to apprehend that a flood is upcoming and how forceful it might be in terms of areas that will be affected as well as the depth of inundation and the assessed duration of the flood incident(Morshed, 2007). Kalur para village is basically Char, and this char is detached from the mainland. There is no convenient way for the early warning system in the study area. Nevertheless, there were seen particular practices. For early warning, there were also some of the local or indigenous knowledge documented during the field survey which is mentioned below:

$\checkmark$ Unfamiliar crying/voices of animals and birds

$\checkmark$ Movement of ants to the higher grounds

$\checkmark$ Chickens spread out their wings in order to dry them up

$\checkmark$ The behavior of the rainfall

Regarding unexpected sounds from the rivers, that time the community people recognize the sound of substantial flood upstream, based on their previous experiences. Muddy smell or altered type of aroma in the water is measured as another sign for flood. Local people stated that habitually when the river bring mud or soil, then the water smell change, and it is also one indicator to know about the upcoming flood disaster. Besides, when the water level is increased, then the river water carries dry leaves, mud and other materials along the river. 


\section{Mll Macrothink}

These are also another indicator of flood forecasting. These indicators are empirically weak but quite workable in areas where no technical good flood forecasting and warning systems are in place. When the flood strike, then the electronic media's news don't reach perfectly due to lack of available appliance of media. In the study area, there are $1.1 \%$ of households have television and $5.6 \%$ of households have a radio which is inadequate than the need. These electronic media don't run regularly owing to insufficient power supply. Besides, the education rate of this area is $17 \%$. Education is also one of the leading indicators to understand the disaster. As the upcoming disaster bulletin is quite technical, that's why the illiterate people don't understand. However, before the flood, the union parisad Chaiman take a step to announce the flood forecast to the vulnerable people by miking, fire flame etc. After that, people make a combination between the announcement of UPC (union parisad chairman) and their local strategies. Then they prepare for upcoming flood based on their afford.

Framework for the local knowledge system: Source, (Dekens, 2007)

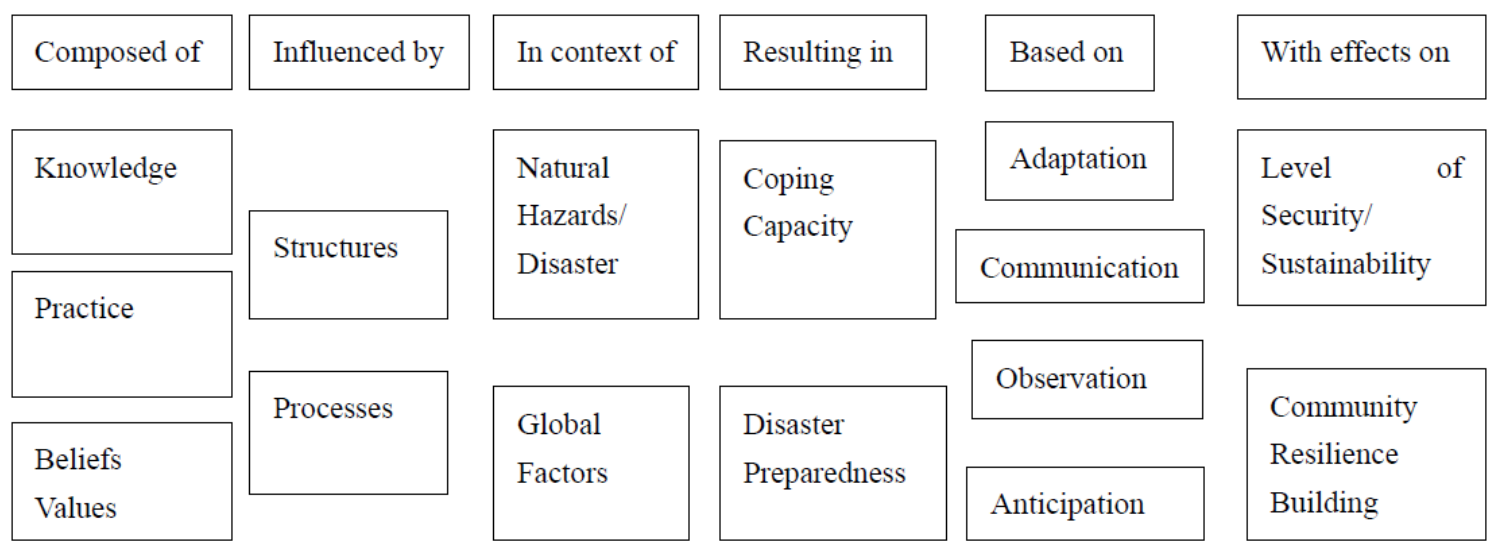

People of the study area usually use indigenous knowledge of their style to protect many kinds of crises like a flood. They are used to this strategy to save their life, households, and other belongings. But it differs upon the educational background of the affected people. There were found some who were well prepared in coping practices, and also some of them are moderately aware regarding the flood disaster. On the other hand, occupation is another excellent influence feature to make them well prepared in coping practice. In this study, the researchers analyze the people indigenous knowledge by three categories, e.g. before the flood, during the flood, and after the flood.

\subsection{Initiatives Taken by People before the Flood}

Generally in the months of June to early October is the exact time to occur flood in the study area. The frequency of flood in this area is high then the other part of this country. Before the flood, the local people usually take some preparation to alleviate the losses as described below. 


\section{Mll Macrothink}

\subsubsection{Household Preparation}

Every year flood hit the study area. Sometimes the impact is less sometimes is high. It depends on the intensity of the flood. During the field survey, the researchers knew that about the real reason this fact. About $85 \%$ of respondents stated that every 8-10 years after we usually face magnitude flood and that time, we are hopeless and helpless. We can't meet any primary needs smoothly even every year we suffer for basic need. And day by day, we are getting more vulnerable. So, when there is a likelihood of the flood disaster, people of the study area follows particular local coping strategies to guard their household from the damaged triggered by the flood. Nearly $69 \%$ of the respondents stated that they tried to mending their household and escalating from the ground level. Some stages are occupied by the local people to defend their household.

- Repair the house (roof, wall)

- Rising the house from the ground

- The higher plinth of the rooms

- Making impermanent Munchan

- Planting grass/trees beside home to minimize soil erosion

- House Protection by bamboo and fence

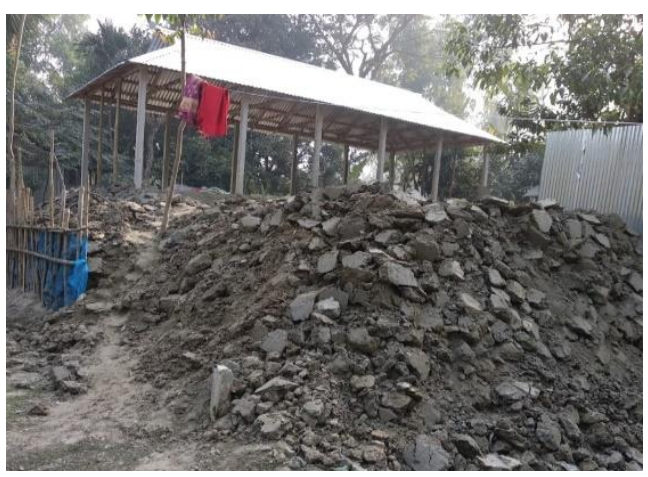

Photo 1: Seasonal homestead earth rising

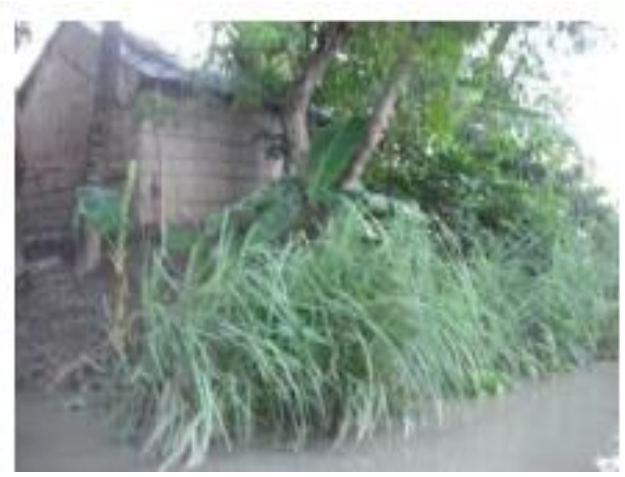

Photo 2: Protection by trees and catkin grass

\subsubsection{Dry and Constant Food Reserves}

During the flood, people don't cook almost in the meal time. Regarding this matter, most of the people who have been affected because of floods recurrently stated that they have attempted to preserve foods prior to the flood. Dry food like Chira, muri, ghur, biscuits, sugar, rice, pulses, salt, oil, etc. are gathered and conserved by vulnerable people. Usually, the people preserve the dry food in polythene bags and big Mokti/Kola (made by mud). On the other hand, storing food, fuel and water use to stockpile by the earthen and plastic pots. In the study area, most of the houses make storing place in high than the normal floor, and when the flood water increase, the people usually prepare a muchan inside the house. After scrutinizing the empirical field data, it showed that nearly $65 \%$ of the households of the study areas were preserved dry food prior to the flood disaster. Besides, some people are slightly rich in this study area; they also kept rice for the entire year or six months in a year as habit either flood 


\section{Macrothink

happens or not. On the other hand, there are some of the poor people who don't have any backup food owing to their economic hardship. Although, the needy people when the likelihood of the flood, they try hard to manage some food from the near market or from the benevolent people.

\subsubsection{Livestock Protection}

Particularly in the low incomes household's livestock are essential assets. Generally, in the study area cattle, buffalo, goats, chicken, ducks, hens, poultry, etc. are the main livestock. During the flood, livestock is also more vulnerable. The respondents replied that when the high flood occurred at that time some of the livestock usually die. So, from this, it causes massive economic loss to the owner of the livestock. Regarding this matter, people take some strategies to protect their livestock before the magnitude flood disaster such as livestock are sent to the flood free relative's areas or high land areas or making some impermanent shade where livestock are kept during the flood period. Though people take caring measures but it is very difficult to protect livestock during the flood period. So, the key scenario of the study area during the flood regarding livestock is seen to force to sell their livestock even though the owner of livestock received fewer prices than they claim. Households' survey data showed that $61.4 \%$ of respondents preferred to move their livestock to safer palaces. When all such measure fails, $63.2 \%$ of respondents reported selling their livestock. Before the flood, the livestock owner usually takes some steps to protect their livestock.

- Sent to the flood free areas

- Making Mancha or shades

- Sell livestock

- Taking with them.

\subsubsection{Crop Production and Preservation of Seeds}

Bangladesh is the mainly familiar agricultural-based economic country in the world. And almost $80 \%$ of people are directly and indirectly relating to agriculture. Due to the flood disaster agriculture sector is significantly affected. When flood attack that time washed away crop fields with green or ready crops. Farmers now and then don't have anything to do to save their crops. For this reason, it is proved that farmers of the mentioned study areas couldn't plant their regular crops regarding this issue that times they take the following dimensions or altering the cropping pattern to safeguard crops prior to the flood.

- Sowing rapid growing paddy and having many leaves vegetables

- Prepare seedbed and sowing seeds in a high place.

- Sowing water resistant vegetables.

- Follow the local crop calendar. 


\section{Macrothink Institute ${ }^{\text {TM }}$}

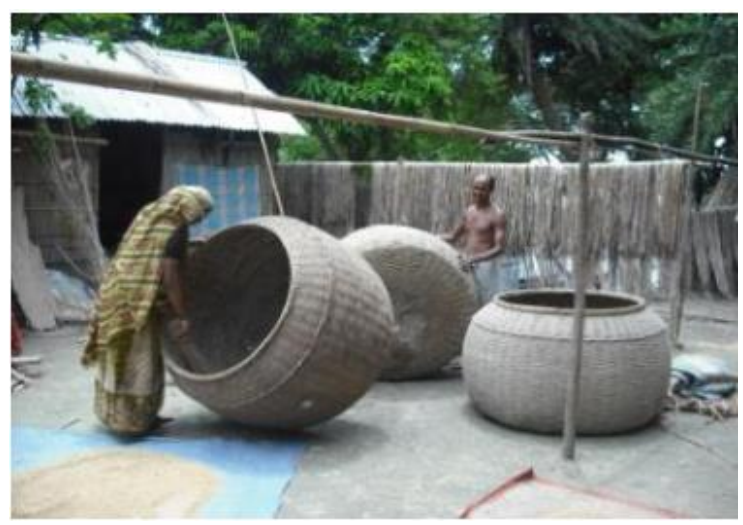

Photo 3: Seed and crop preservation

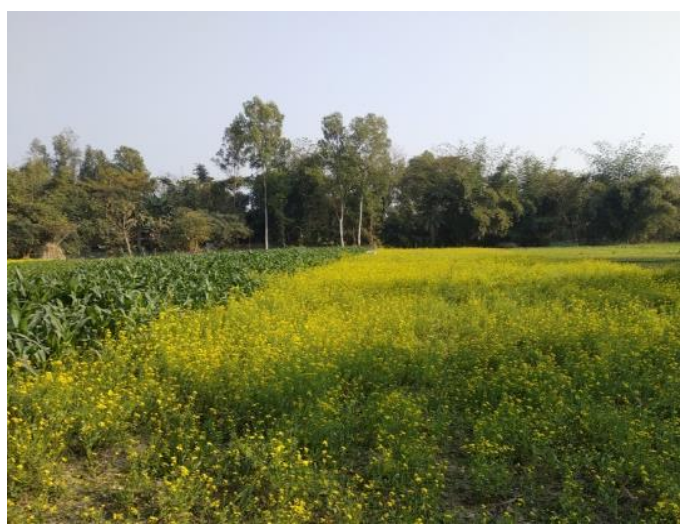

Photo 4: Sowing rapid growing crops in the study area

As agriculture is an important feature of the study area, for this reason, are being conscious about seed preservation. But it is a very continuous process of the people of the study area. From this study, it is revealed that most of the farmers found to preserve agriculture seeds. Because they always seem that they couldn't find seeds for cultivation after the flood. Besides, farmers are practiced to preserve seeds from a long day back for cultivation purpose. Before the flood, they usually preserve seeds by gola (seed basket) big box, sack crock, etc. The exploratory findings showed that about $57 \%$ of respondents preserved seeds before the 2017 flood. They also believed that during the flooding seeds might not be available and also may be costly. Many poor farmers have no money to buy seeds for cultivating; that's why they do keeping preserve. Besides, some of the respondents told that they don't have preserve seeds as they have no flood protected place to conserve seeds.

\subsubsection{Removal of Assets}

Whereas flood is a disaster, so when it occurs all property has been spoiled. Regarding this point of view, poor people are very much frightened regarding the destruction of their toilsome properties owing to flood. If there is a change to attack flood of the area, they try to their level best to save their assets like house, livestock, agricultural land, crops, fishery, etc. But if they don't manage or protect their asset, then they sell their properties even when they receive smaller money. So, the needy people who sell their all properties they have to take shelter either in town or in the shelter center with his family members for a long time. After taking shelter in shelter center, they decide to go to town looking for jobs like rickshaw pulling, day laborer, hawker, etc. Because in the study area almost $81 \%$ of people are illiterate, that's why they search these kinds of job. Besides, many of them do not sell their assets and try hard to protect. 


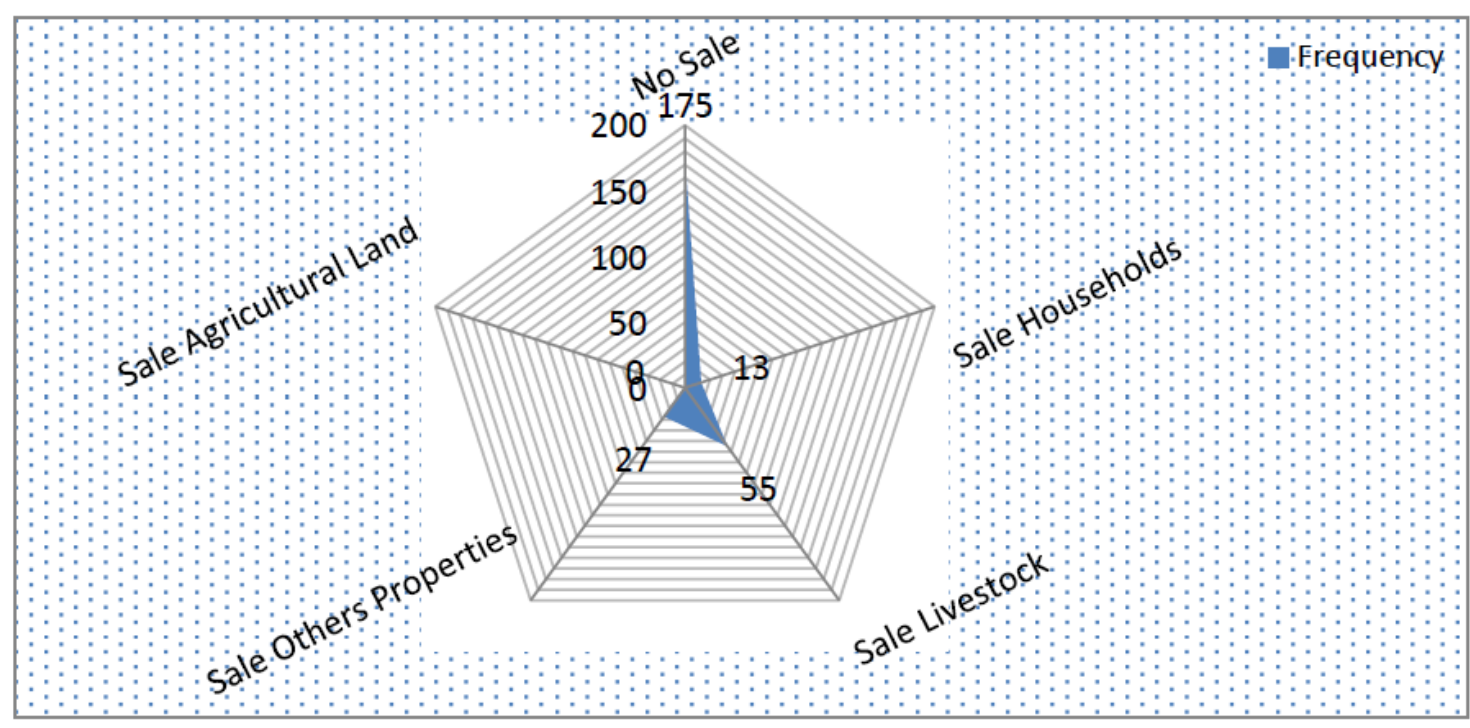

Figure 6. Removal of assets of the people

The above discussion showed that 175 of respondents did not sell their assets and respectively 14, 55 and 27 of respondents sold households, livestock, and other properties in 2017 flood. On the other hand, there are no people who did not sell their agriculture land.

\subsection{Initiatives Taken by People during the flood}

During the flood, the stranded people have to suffer more. They are living very an unfeeling life due to catastrophe surroundings and they take some strategy to alleviate their suffering, losses, and damages. The strategies are discussed below:

\subsubsection{Taking Shelter}

When the extreme flood hit an area at that time, all houses inundated due to intrusion flood water. For this reason, the trapped people have to leave their homes as soon as possible and take shelter to save their life near the highway, school, and flood shelter centers, and at the top of the house roof, etc. There is a very few flood shelter have in the study area. So the affected people are usually taking shelter in the nearby high land places as shelter. Due to a very few flood center, the affected people are getting more vulnerable and losing their lives and valuable property. Sometimes people are going to nearby towns to live safely. In the 2017 flood period, most of the people about $62 \%$ of respondents did not leave their houses; they tried to stay their houses like making high place/ Mancha, roof, on the boat, making boat by banana trees shell. The affected people also reported that they did not leave their home during the flood because of homesickness. Even though they know that if they stay during the flood in homestead then they get more pain thereafter they stay. The local people always say, mori ar bachi terporer baba dader veta charbo na, morle akhana mormo (we are dying or alive, we won't go elsewhere from our father and grandfather homestead, rather than we will die here.). And $38 \%$ of people of the study area who left home and took shelter to nearby flood free regions. But one thing is crucial that the researchers found from the respondents who reported 


\section{Ml Macrothink}

that during the flood they make a group by their nearest neighbor and they more pay attention to the children and older people. Children and older people are more victims during the flood. So, during the flood, the group of members sent the older and children to safer flood free places. Almost all households followed this phenomenon.

\subsubsection{Collection of Pure Drinking Water and Medicine}

Pure drinking water is essential for a human being. During the flood period, drinking water is highly polluted. People can't drink pure water due to water pollution. The study revealed that almost $98 \%$ of people are drinking water from the tube well and rests of people are collecting their drinking water by other sources. Every year the study areas people are facing flood disaster. But the intensity of flood is not the same every year. Sometimes the impact of the flood is high and sometimes less. When the high flood hits in the study are like 2017 flood that time, the stranded people are not capable of collecting pure drinking water from the tube well. So, at this time, people are suffering for pure drinking water. But this time people make some strategies to collect drinking water such as use purify tablet to get pure water, boiling water for getting drinking water. When they are failed to purify then they drink unsafe water. Besides, the affected people also use crock to preserve drinking water.

On the other hand, when the normal flood hits that time, some of the houses sink due to flood water and some of the houses do not sink. So, the flood-affected people collect pure drinking water from the tube well, which does not go under water. Polluted water always caused water-borne diseases. During the flood, people are being sick because of unhealthy circumstances. So, this time medicine is the inalienable part. Usually, the affected peo people collect medicine and slain prior to flood for their treatment.

\subsubsection{Cooking Place and Fuel Stock Capacity}

During the flood, the Char-women don't cook in their conventional kitchen because of submerged. So, before the flood, the Char women usually made portable mud stove (Chula). At the same time, they conserve some fuel materials such as dry wood, jute stick, husk, cow-dung cakes used as fuel, dry leaves, and branches of trees etc. When flood water comes, and the regular kitchen overwhelmed under the water, the Char-dwellers usually cook on the temporary raised platform or on the boat. The char land people stored the fuel on the big trees and build raised bamboo platforms with plastic cover during the flood period.

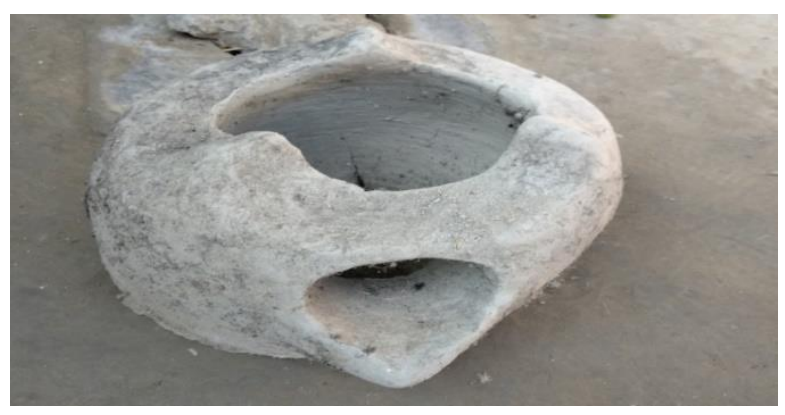

Photo 5. Mud stove stored for flood season 


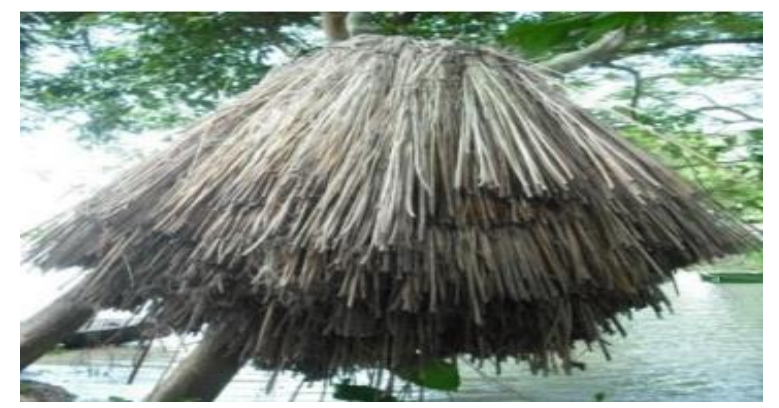

Photo 6. Fuel stockpile hanging on the tree for flood period

\subsubsection{Food Habit Changing and Reduce Food Consumption}

Whereas, during the flood, all of the things submerged, for this reason, people can't conduct their normal life. In this time people lifestyle directed adversely. So, people are being obliged to change their food habit and food consumption. Actually, people can't reserve more food during flood period owing to their hardship. Most of the people of the study area are very poor that's why they can't reserve extra food for the flood period. Besides, some people are comparatively rich than the other people in this area. They are sometimes reluctant to change food habit and food consumption, but when the flood hits in this area that time rich people also try to change their food habit and consumption, and also they pay attention to reserve dry food. And for the stranded people who are bound to change their food habit and food consumption because they are running their life hand to mouth.

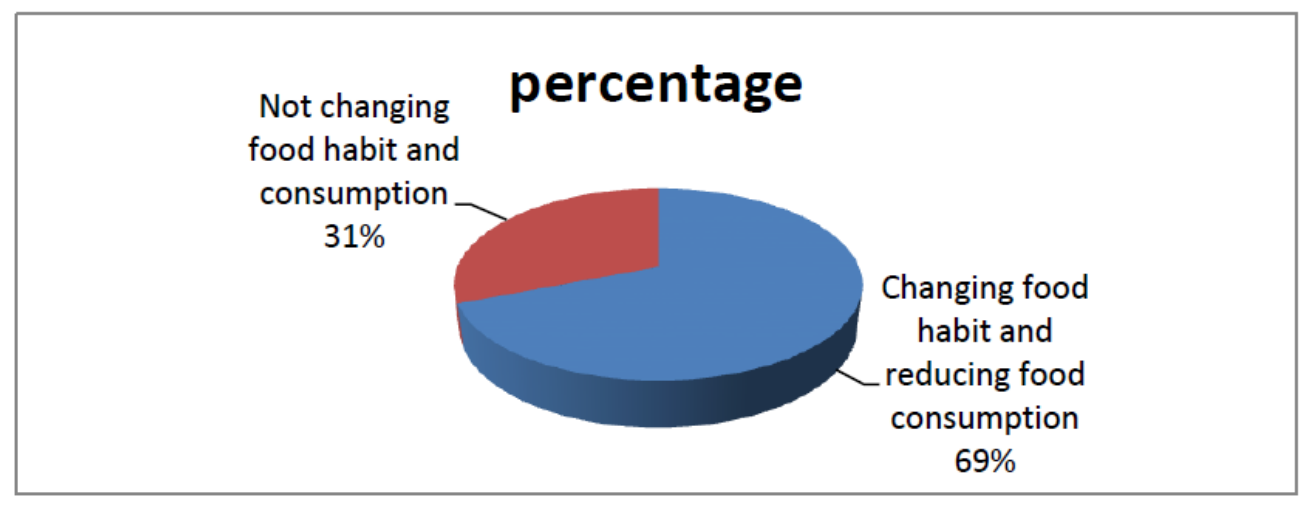

Figure 7. Changing food habit and reducing food consumption

The above figure showed that $69 \%$ of households changed their food habit and consumption, and only $31 \%$ of households did not change their food habit and consumption in the 2017 flood period.

\subsubsection{Changing Occupation and Transportation Mode}

Most of the people of this area become unemployed when the flood occurs and also they are 
bounded to change their occupation. To meet the basic need of their family member, they try to engage in work. Actually, altering occupation depends on the availability of work in their neighboring area or the place where they are living. Many of them migrate from village to nearby town for getting work to meet their basic family needs. Because in Bangladesh, the flood is one of the main reason for migration from one place to another place(Khatun, 2013). On the other hand, some of them are involved in fishing (catching \& sell), boating, daily labor, etc. The survey data found that around $15 \%$ of the people were provisionally altered their occupation during the flood period. After the flood, these people join theirs before work. But the most scenarios, during the flood, people were workless and hopeless. The respondents stated that in the flood period they couldn't manage work to earn some money. And they also said that they were busy to save their life and homestead during the flood. During the flood, the communication system is being much worsened. All kind of communication hampered significantly. The transport couldn't run on the road. The condition is more recurrent in the most vulnerable parts of the kalur para village. So, this time, people usually use the mode of transportation such as a boat, banana tree raft (vela), Bamboo raft, etc.

\subsection{Initiatives Taken by the People after Flood}

After the flood, the picture of the affected area different character, especially those who are being affected has been found more suffered. In the post-flood period, most of the people don't have work; houses are damaged, not available pure drinking water and food, and also suffered water-borne diseases, etc. And this kind of scenery is more frequent in almost every affected area. So, people try to manage their unfavorable condition asap by dint of any kind of taking strategies such as taking a loan from NGOs, money lenders and Govt. organization, etc.

\subsubsection{Financial Coping Strategies}

After the flood, not only scarcity of job but also the income of the people reduces enormously. The household income is not adequate to cope with the flood. Therefore, money is the most vital need in most of the crisis period. Especially Char dwellers are poor people in Bangladesh (Kabir, 2006), (Strategy \& Plan, 2009) and who are suffer more. As the post-flood period, the condition of people money solvency is not healthy due to their longtime workless.

For this reason, they take a loan from different sources. About $33 \%$ of the respondents took cash loan from various organizations to meet their basic needs and repairing their house and also for other purposes. Besides, some of the respondents (12\%) stated that they arranged money for the same purposes from their relatives and local money lenders (Mohajon). On the contrary, some of the respondents got to financial solvency by selling land, livestock, housing materials, and personal belongings.

\subsubsection{Household Repairing}

Due to the extreme flood of 2017 , about $65 \%$ of houses damaged partially and about $35 \%$ of homes damaged fully. So, after the flood needs to recover their houses. Regarding this issue, 
$59 \%$ of respondents revealed that they repair houses as required time, and $41 \%$ of respondents answered that they didn't repair their house as required time. From this study, it is cleared that all of respondent's socio-economic condition and their loan managing capacity quality wasn't the same.

\subsubsection{Crops Diversification and Strategies}

After the flood, when the flood water is gone away from the agricultural fields at that time, the farmers take some different strategies to cultivate various crops. They also bring diversification in their crops. Especially they sow rapidly grown crops for getting solvency. In the study area, the rapid grown crops are ginger, onion, garlic, tomato, cucumber, pepper, and various vegetables, etc. After the rapid crops, they also take a decision which land is higher than the other land and according to this judgment; they cultivate the crops like aman and boro. If they find any high land and it's appropriate to cultivate long term crops then they cultivate. From the field survey, it found that about $51 \%$ of people were taking this kind of strategies regarding their crops cultivation.

\subsubsection{Exploring New Work Opportunities}

People of kalur para village suffered more after the flood. The stranded people had no works at this time. So, a long time they couldn't manage any work. From the field survey, it revealed that some of the people had gone to near and far town to find a work such as a rickshaw puller, street vendor, day labor after the flood period. On the other hand, who have some land; they hard work to cultivate crops. And also some of the people were engaged in day labor. In the study area, most of the people are involved in the agriculture-related occupation.

\subsubsection{Others}

When a flood hits that time most of the infrastructures such as roads, bridge, culverts, embankments are destroyed. So, after the flood people of this area are seen to repair infrastructures. Regarding this matter, demands more money and resources. Usually, these types of work are done by the local government. On the other hand, sometimes NGOs and local people work in this regard.

Regarding this issue, people of the flood-affected who also make the team to repair the infrastructures in their way. About $79 \%$ of people reported that they work in this regard with the different organizations. Besides, in the flood-prone areas like Char who are educated, they usually encourage the students with the various organizations to go to school and tell them the importance of education facilities.

\section{Conclusion}

Flood is such kind of environmental concern that can change the environment within a short instant. It is deliberated as one of the main problems in Bangladesh, which occurred recurrently almost every year. There are many low lying areas of the country which are brutally affected by the flood disaster involving Char land areas. Flood is a part of the lives of the people of Kalur Para Char land. The study finds that the flood has a terrible impact on 
people's socio-economic condition. Therefore, most of the people of this area lost their crops, damaged households, infrastructures, livestock, and income generating activities as well as food distribution systems. During the flood, the affected people were suffering a lack of available food, drinking water, sanitation and convenient communication system in this area. They also were suffering from various diseases such as diarrhoea, typhoid, dysentery, cold and fever, skin diseases, etc. Especially in this study area, most of the people are willing to live because of some advantages such as low cost of land, the existence of demesne (Khas Jami), etc. People of this area live here their entire lives fight against the flood.

It is evident that in response to the flood disaster, people of Kalur Para Char adopt various indigenous knowledge and alleviating measures in their way. This study indicates that the households adopted some measures before, during and after the flood such as preventive measure, adaptive measure, and distress mitigation. Indigenous coping strategies were indispensable in low magnitude flood like an annual flood. On the basis of study area characteristics that aforementioned, the study area is familiar to the recurrent flood disaster. So when the normal flood happened then indigenous knowledge tends to be effective to alleviate and mitigation the flood, but in the perspective of the high flood (once in 8-above years, 1988,1998, 2004, 2017) of the study area, it's quite challenging to manage. Because, this study revealed that majority of the respondents live under extreme poverty, the education rate below 20\%, people's low income, lack of available work, river bank erosion, etc. Thus these kinds of features are not susceptible to tackle the extreme flood. As Tod and Thompson cautioned, these kinds of tactics have inadequate effect in decreasing damage in more extreme cases (Thompson \& Tod, 1998). Besides, when the severe flood hit in this study area, then people want more help from the various organizations, including government organization. But the common scenario is that they don't get proper guidance to survive. External support such relief at the suitable time and suitable distribution can play a vibrant role in determining the efficiency of coping strategies. Haque CE and M.Q Zaman have also made a similar argument that external support and assistance contribute to rapid recovery from a flood disaster (Haque \& Zaman, 1993). In conclusion, the present study showed that even though flooding in Kalur Para Char makes socio-economic and health-related threats and environmental and infrastructural damage. Regarding this, indigenous coping strategies can knowingly reduce vulnerability to disaster. Numerous of the adaptive approach engaged takes place to be short-term processes which are not defensible. This is also replicated by the external assistance that the community obtains after a magnitude flood disaster. So, these strategies are useful only in a low flood. When the flood water rises, and crosses the risk line, then people have no choice they relocate to a higher place.

\section{Acknowledgments}

I would like to express my sincere appreciation to my study respondents who were patient interviewees and provided necessary information for this study. I shall never forget their sincere cooperation and support.

\section{References}

Adham, M., \& Rubayet, I. (2010). Upgrading homesteads to flood shelters in char Kochkhali. 
Gaibandha. BRAC University.

Ahamed, R. (2001). Impact of Bank Erosion of the Jamuna River on selected towns in the Northern Region of Bangladesh. Phd Report, Department of Geography and Environment, Jahangirnagar University, Savar, Dhaka.

Antweiler, C. (1998). Local knowledge and local knowing. An anthropological analysis of contested" cultural products' in the context of development. Anthropos, 469-494.

Bajracharya, D. (1983). Fuel, food or forest? Dilemmas in a Nepali village. World Development, 11(12), 1057-1074. https://doi.org/10.1016/0305-750X(83)90100-6

Bank, W. (1998). Indigenous knowledge for development: A framework for action. Knowledge and learning center, Africa Region.

Baqee, A. (1998). Peopling in the land of Allah Jaane. Power, peopling and environment: the case of char-lands of Bangladesh. Peopling in the land of Allah Jaane. Power, peopling and environment: the case of char-lands of Bangladesh.

Barkat, A., Roy, P. K., \& Khan, M. S. (2007). Charland in Bangladesh: Political economy of ignored resource: Pathak Shamabesh.

Berkes, F. (1999). Sacred ecology: traditional ecological knowledge and management systems: Taylor \& Francis, Philadelphia.

Berkes, F., Colding, J., \& Folke, C. (2000). Rediscovery of traditional ecological knowledge as adaptive management. Ecological applications, 10(5), 1251-1262.

https://doi.org/10.1890/1051-0761(2000)010[1251:ROTEKA]2.0.CO;2

Brokensha, D. W., Warren, D. M., \& Werner, O. (1980). Indigenous knowledge systems and development: University Press of America.

Cadag, J. R. D., \& Gaillard, J. (2012). Integrating knowledge and actions in disaster risk reduction: the contribution of participatory mapping. Area, 44(1), 100-109.

https://doi.org/10.1111/j.1475-4762.2011.01065.x

Cochran, W. G. (1977). Sampling Techniques: 3d Ed: Wiley New York.

Dekens, J. (2007). Local knowledge for disaster preparedness: A literature review: International Centre for Integrated Mountain Development (ICIMOD).

Edwards, M. (2000). Community guide to development impact analysis. Madison, WI: University of Wisconsin-Madison.

Elahi, K. M., \& Rogge, J. (1991). Riverbank Erosion, Flood and Population Displacement in Bangladesh. Jahangirnagar University, Dhaka: REIS.

Flavier, J. M., Jesus, A. D., \& Navarro, C. S. (1995). The regional program for the promotion of indigenous knowledge in Asia. https://doi.org/10.3362/9781780444734.043

Gaillard, J.-C., \& Mercer, J. (2013). From knowledge to action: Bridging gaps in disaster risk 
reduction. Progress in human geography, 37(1), 93-114.

https://doi.org/10.1177/0309132512446717

Gruntfest, E. (1995). Long-term social and economic impacts of extreme floods. Paper presented at the US-Italy Research Workshop on the Hydrometeorology, Impacts, and Management of Extreme Floods, Perugia, Italy.

Hakim, S. (2012). Reduction of flood risk by indigenous knowledge at Alekdiar Char of Shibalaya Upazila in Manikganj district. BRAC University.

Haque, C. E., \& Zaman, M. Q. (1993). Human responses to riverine hazards in Bangladesh: a proposal for sustainable floodplain development. World Development, 21(1), 93-107. https://doi.org/10.1016/0305-750X(93)90139-Z

Islam, A. S., Haque, A., \& Bala, S. K. (2010). Hydrologic characteristics of floods in Ganges-Brahmaputra-Meghna (GBM) delta. Natural hazards, 54(3), 797-811. https://doi.org/10.1007/s11069-010-9504-y

Islam, M., Hasan, T., Chowdhury, M., Rahaman, M., \& Tusher, T. (2012). Coping techniques of local people to flood and river erosion in char areas of Bangladesh. Journal of Environmental Science and Natural Resources, 5(2), 251-261.

https://doi.org/10.3329/jesnr.v5i2.14827

Islam, M., Sultana, S., Saifunnahar, M., \& Miah, M. (2014). Adaptation of char livelihood in flood and river erosion areas through indigenous practice: A study on Bhuapur riverine area in Tangail. Journal of Environmental Science and Natural Resources, 7(1), 13-19. https://doi.org/10.3329/jesnr.v7i1.22138

Islam, M. S. (2007). Indigenous knowledge \& natural disaster preparedness in char land of Bangladesh. BRAC University.

Islam, M. S., Solaiman, M., Islam, M., Tusher, T., \& Kabir, M. (2015). Impacts of flood on Char livelihoods and its adaptation techniques by the local people. Bangladesh Journal of Scientific Research, 28(2), 123-135. https://doi.org/10.3329/bjsr.v28i2.26783

Ives, J. D. (1989). Deforestation in the Himalayas: the cause of increased flooding in Bangladesh and northern India?. Land Use Policy, 6(3), 187-193.

https://doi.org/10.1016/0264-8377(89)90051-3

Kabir, R. D. (2006). The state of char education in Bangladesh: focus on selected chars of Gaibandha district. Asian affairs, 28(3), 5-24.

Kar, K., \& Hossain, F. (2001). Mobility of people of Chars and river banks of Bangladesh-a study of Gaibandha District. Dhaka, DFID-Bangladesh, unpublished mimeo.

Khan, M. M. H., \& Nahar, N. (2014). Natural disasters: socio-economic impacts in Bangladesh. Banglavision, 13(1), 58-67.

Khatun, M. (2013). Climate Change and Migration in Bangladesh: Golden Bengal to Land of Disasters. Bangladesh e-journal of Sociology, 10(2). 
Maferetlhane, O. (2012). The role of indigenous knowledge systems in disaster risk reduction: a critical analysis.

Management, D. O. D. (2017). Flood Situation. DM, Bangladesh.

Mavhura, E., Manyena, S. B., Collins, A. E., \& Manatsa, D. (2013). Indigenous knowledge, coping strategies and resilience to floods in Muzarabani, Zimbabwe. International Journal of Disaster Risk Reduction, 5, 38-48. https://doi.org/10.1016/j.ijdrr.2013.07.001

Mercer, J., Gaillard, J.-C., Crowley, K., Shannon, R., Alexander, B., Day, S., \& Becker, J. (2012). Culture and disaster risk reduction: lessons and opportunities. Environmental Hazards, 11(2), 74-95. https://doi.org/10.1080/17477891.2011.609876

Morshed, M. (2007). Indigenous coping mechanisms in combating flood. BRAC University.

Munna, T. I. (2007). Floods in Bangladesh: Possible Causes and Solutions. ICIMOD three decades for mountains and people.

Najmul Islam, M., Zahurul Islam, M., \& Fujita, K. (2011). Coping with flood disaster: Household level responses by the char-dwellers on the river Padma in Bangladesh. Indian Journal of Power and River Valley Development, 61(9), 159.

Nirapad. (2017). Flood Situation Updated. reliefweb. int, 22, 1-12.

Rahman, S. U. (2014). Impacts of flood on the lives and livelyhoods of people in Bangladesh: A case study of a village in Manikganj district. BRAC University.

Rasid, H., \& Paul, B. K. (1987). Flood problems in Bangladesh: Is there an indigenous solution?. Environmental Management, 11(2), 155-173. https://doi.org/10.1007/BF01867195

Roy, M., Syed, S., \& Azim, A. (2007). Settlement of a Char land Community: A Study on Social Crisis and Coping Pattern. Paper presented at the A paper presented at the seminar organized Bangladesh Economic Association, Dhaka, Bangladesh.

Schmuck-Widmann, H. (2001). Facing the Jamuna River: Indigenous and engineering knowledge in Bangladesh: Bangladesh Resource Centre for Indigenous Knowledge.

Sharma, C. K. (1991). Energy and Environment in Nepal. Ambio, $X X(3-4), 120-123$. https://doi.org/10.1177/0958305X9100200408

Sillitoe, P. (1998). The development of indigenous knowledge: a new applied anthropology. Current anthropology, 39(2), 223-252. https://doi.org/10.1086/204722

Strategy, B. C. C., \& Plan, A. (2009). Ministry of Environment and Forests. Government of the People's Republic of Bangladesh, Dhaka, Bangladesh.

Tajrin, M. S., \& Hossain, B. (2017). The Socio-Economic Impact Due to Cyclone Aila in the Coastal Zone of Bangladesh. International Journal of Law, Humanities \& Social Science, $1(6), 60-67$.

Thompson, P., \& Tod, I. (1998). Mitigating flood losses in the active floodplains of 
Bangladesh. Disaster Prevention and Management: An International Journal, 7(2), 113-123. https://doi.org/10.1108/09653569810216333

Thrupp, L. A. (1989). Legitimizing local knowledge: From displacement to empowerment for Third World people. Agriculture and Human Values, 6(3), 13-24.

https://doi.org/10.1007/BF02217665

Tod, I. (2007). Assessment of the effectiveness of the homestead raising and mound protection works implemented by the Shouhardo program. CARE Bangladesh.

UNEP. (2001). Bangladesh: State of the Environment 2001. United Nations Environment Program (UNEP).

Zaman, M. (1988). Jore-Jar-Jomi-Tar: A Case for Reform in Char Land Policies and Administration in Bangladesh. Riverbank Erosion Impact Study (REIS), Jahangirnagar University, Savar, Bangladesh.

Zaman, M., \& Wiest, R. (1991). Riverbank erosion and population resettlement in Bangladesh. Practicing Anthropology, 13(3), 29-33.

https://doi.org/10.17730/praa.13.3.f8p0g77111621707

\section{Copyright Disclaimer}

Copyright for this article is retained by the author(s), with first publication rights granted to the journal.

This is an open-access article distributed under the terms and conditions of the Creative Commons Attribution license (http://creativecommons.org/licenses/by/3.0/). 